УДК 617.711-004.1 : $339.13: 615.4$

DOI https://doi.org/10.11603/2312-0967.2019.4.10627

\title{
ЗАСОБИ ДЛЯ ЗАМІСНОЇ ТЕРАПІЇ СИНДРОМУ СУХОГО ОКА: АНАЛІЗ ФАРМАЦЕВТИЧНОГО РИНКУ УКРАЇНИ
}

\author{
О. В. Кривов'яз, Ю. О. Томашевська \\ Вінницький національний медичний університет імені М. І. Пирогова \\ 16124sk@gmail.com
}

ІНФОРМАЦІЯ

Надійшла до редакції / Received: 04.11.2019

Після доопрацювання / Revised:

07.11 .2019

Прийнято до друку / Accepted: 12.11.2019

\section{Ключові слова:}

синдром сухого ока;

замісна терапія;

замінники слізної рідини;

маркетинговий аналіз.
АНОТАЦІЯ

Мета роботи. Аналіз асортименту засобів для замісної терапії синдрому сухого ока (ССО), наявних на фрармацевтичному ринку України.

Матеріали і методи. Маркетинговий, статистичний, структурний, графрічний. Результати й обговорення. Серед засобів для місцевої замісної терапії CCO нараховується 11 лікарських засобів групи S01X A20 - «Штучні замінники слізної рідини та інші нейтральні препарати» та 24 зареєстрованих як медичні вироби, в тому числі 1 багатоцільовий розчин (група 03. Офртальмологічні та оптичні вироби), 16 засобів для офтальмологічного використання (група 03. Офртальмологічні та оптичні вироби) та 7 розчинів для промивання, зрошення, лікування (група 13. Інші вироби для лікування). Під час аналізу форм випуску засобів для замісної терапії виявлено, що в Україні вони представлені у чотирьох формах: очних крапель, очного гелю, розчинів, емульсії. Асортиментний аналіз за країною-виробником свідчить про широку географрію розташування потужностей виробництв. Механізм дії даних засобів забезпечує наявність таких активних інгредієнтів, як натрію гіалуронат, карбомер, гіпромелоза, кармелоза, поліквад, повідон, полівініловий спирт, декспантенол із таурином, трегалоза, комплекс вітамінів з амінокислотами, ектоїн, омега-3, поєднання натрію гіалуронату з пропіленгліколем та гуаром.

Висновки. Для замісної терапії ССО в Україні використовується 35 найменувань засобів у фрормі очних крапель, очного гелю, розчинів та емульсії. Майже 90 \% з них випускають у фрлаконах по 3, 5, 10 чи 15 мл. Більшість - 80 \% - засобів для замісної терапії ССО імпортують в Україну 3 країн Європи. До складу 17 найменувань входить натрію гіалуронат в якості діючої субстанції.

Таким чином, в результаті проведених досліджень варто виділити відсутність засобів для замісної терапії ССО у формі мазей. Крім того, слід звернути увагу як на недостатню кількість засобів зазначеної групи вітчизняного виробництва загалом, так і обмежений асортимент активних інгредієнтів, представлений лише натрію кармелозою, таурином із декспантенолом, а також натрію гіалуронатом.
Вступ. Синдром сухого ока (ССО) є однією з найбільш розповсюджених патологій органа зору. Від захворювання страждає 9-18\% населення розви- нених країн світу, а частота його виявлення має тенденцію до постійного зростання. Так, протягом 30 років вона зросла майже в 5 разів. Практично кож-

ISSN 2312-0967. Pharmaceutical review. 2019. № 4 
Фармацевтичний менеджмент, маркетинг та логістика Pharmaceutical management, marketing and logistics

ному другому пацієнту при первинному зверненні до офтальмолога встановлюють такий діагноз. Цю патологію мають близько 12 \% хворих офртальмологічного профілю віком до 40 років і понад 67 \% старше 50 років [1].

CCO - це багатофракторне захворювання поверхні ока (структур ока та його придаткового апарату: рогівки, кон'юнктиви, повік, слізної плівки, слізних та мейбомієвих залоз). Воно характеризується втратою гомеостазу слізної плівки та супроводжується очними симптомами. При цьому етіологічну роль відіграють нестабільність слізної плівки, її гіперосмолярність, пошкодження поверхні ока, запалення та нейросенсорні порушення [2].

Зважаючи на фрізичний та психологічний дискомфрорт, якого завдає ССО пацієнтам, це захворювання має суттєвий негативний вплив на якість їхнього життя. Крім того, наявність ССО може призвести до погіршення або спотворення результатів хірургічного лікування офтальмологічних патологій (зокрема, катаракти та ресрракційної хірургії) [3].

Ведення пацієнтів із ССО складне і включає використання як консервативних, так і оперативних методик. Лікування спрямоване на відновлення дефріциту слізної рідини і стабілізацію слізної плівки, а також на купірування супутніх ксерозу змін очей і організму. Заміщення деоріциту слізної рідини і стабілізація слізної плівки включає використання штучних замінників сльози у формі очних крапель і гелів, створення умов для зниження відтоку слізної рідини 3 кон'юнктивальної порожнини, стимулювання сльозопродукції [1].

Всі варіанти лікування мають за мету зменшення ознак та симптомів (подразнення ока, почервоніння або слизові виділення), підтримку та покращення зорової фрункції, зменшення структурних ушкоджень або запобігання їх розвитку $[3,4]$.

Терапія ССО залежно від етіологічних чинників та ступеня тяжкості на ранніх стадіях захворювання починається, як правило, з безрецептурних сльозозамінників [2-4].

Тому метою роботи став аналіз асортименту засобів для замісної терапії ССО, наявних на фрармацевтичному ринку України

Матеріали і методи. Для проведення дослідження було використано дані Державного реєстру лікарських засобів України [5], Державного реєстру медичної техніки та виробів медичного призначення [6], довідника лікарських засобів Компендіум [7], довідника еквівалентності лікарських засобів Rx index [8].

Аналіз інфрормації здійснювали маркетинговим, статистичним, структурним та графічним методами.

Результати й обговорення. В результаті аналізу наявних на фрармацевтичному ринку України засобів для місцевої замісної терапії ССО було нараховано 35 найменувань. Проте у даних довідника лікарських засобів Компендіум та довідника еквівалентності лікарських засобів Rx index було виявлено відмінності щодо приналежності засобів АРТЕЛАК®, краплі очні, розчин, 3,2 мг/мл по 10 мл у фрлаконі з крапельницею; по 1 фрлакону 3 крапельницею в коробці і ГІПРОМЕЛОЗА-П, краплі очні 0,5 \% контейнер-крапельниця 10 мл, № 1. Так, за даними довідника лікарських засобів Компендіум АРТЕЛАК®, краплі очні, розчин, 3,2 мг/мл по 10 мл у фрлаконі з крапельницею; по 1 фрлакону з крапельницею в коробці віднесено до лікарських засобів групи S01X A20 - «Штучні замінники слізної рідини та інші нейтральні препарати», а ГІПРОМЕЛОЗА-П, краплі очні 0,5 \% контейнер-крапельниця 10 мл, № 1 зареєстрована як «офртальмологічні та оптичні вироби». Водночас за АTXкласифікацією, наведеною в довіднику еквівалентності лікарських засобів Rx index, виділено окрему групу лікарських засобів S01K A02 - Гіпромелоза, до якої належить як АРТЕЛАК®, краплі очні, розчин, 3,2 мг/мл по 10 мл у фрлаконі 3 крапельницею; по 1 фрлакону 3 крапельницею в коробці, так і ГІПРОМЕЛОЗА-П, краплі очні 0,5 \% контейнер-крапельниця 10 мл, № 1.

Тому було прийнято рішення про необхідність уточнення даних відповідно до інфрормації Державного реєстру лікарських засобів України та Державного реєстру медичної техніки та виробів медичного призначення. Встановлено, що АРТЕЛАК®, краплі очні, розчин, 3,2 мг/мл по 10 мл у фрлаконі 3 крапельницею; по 1 фрлакону з крапельницею в коробці внесено до Державного реєстру лікарських засобів України, а ГІПРОМЕЛОЗА-П, краплі очні, 0,5 \% контейнер-крапельниця 10 мл, № 1 - до Державного реєстру медичної техніки та виробів медичного призначення. Таким чином, у подальшому при проведенні дослідження користувались цими даними.

Отже, серед засобів для місцевої замісної терапії ССО нараховується 11 лікарських засобів групи S01X А20 - «Штучні замінники слізної рідини та інші нейтральні препарати» та 24 зареєстрованих як медичні вироби, в тому числі 1 багатоцільовий розчин (група 03. Офтальмологічні та оптичні вироби), 16 засобів для офртальмологічного використання (група 03. Оортальмологічні та оптичні вироби) та 7 розчинів для промивання, зрошення, лікування (група 13. Інші вироби для лікування) (табл. 1).

Таким чином, частка лікарських засобів в загальному масиві засобів для замісної терапії ССО становить $31,43 \%$.

На наступному етапі дослідження вивчали форми випуску досліджуваної групи засобів. Встановлено, що лікарські засоби групи S01X A20 - «Штучні замінники слізної рідини та інші нейтральні препарати» представлено у двох фрормах: очні краплі (8 найменувань - 72,7 \%) та очні гелі (3 найменування - 27,3\%). Водночас всі засоби, зареєстровані як медичні вироби, представлено на фрармацевтичному ринку у рід-

ISSN 2312-0967. Фармацевтичний часопис. 2019. № 4 
Фармацевтичний менеджмент, маркетинг та логістика Pharmaceutical management, marketing and logistics

Таблиця 1

Номенклатура засобів замісної терапії синдрому сухого ока, зареєстрованих в Україні

\begin{tabular}{|c|c|}
\hline Група за АТХ-класифрікацією & Найменування засобу \\
\hline 1 & 2 \\
\hline \multicolumn{2}{|r|}{ Лікарські засоби } \\
\hline \multirow{11}{*}{$\begin{array}{l}\text { S01X A20 - Штучні } \\
\text { замінники слізної рідини та } \\
\text { інші нейтральні препарати }\end{array}$} & $\begin{array}{l}\text { АРТЕЛАК® краплі очні, розчин, 3,2 мг/мл по } 10 \text { мл у фрлаконі з крапельницею; по } 1 \\
\text { фрлакону з крапельницею в коробці }\end{array}$ \\
\hline & ВІДІСІК гель очний 0,2% по 10 г у тубі; по 1 тубі в картонній коробці \\
\hline & $\begin{array}{l}\text { штучНІ СльОЗИ краплі очні по } 5 \text { мл або } 10 \text { мл, або } 15 \text { мл у фллаконі-крапельниці } \\
\text { Дроп-Тейнер®; по } 1 \text { фрлакону-крапельниці у коробці з картону }\end{array}$ \\
\hline & ОПТІВЕ® краплі очні по 3 мл, 10 мл, 15 мл у фрлаконах-крапельницях № 1 \\
\hline & $\begin{array}{l}\text { ОФТАГЕЛЬ® гель очний, 2,5мг/г, по } 10 \text { г у фрлаконі, по } 1 \text { фрлакону в картонній } \\
\text { коробці }\end{array}$ \\
\hline & $\begin{array}{l}\text { ОФТОЛІК краплі очні по } 5 \text { мл або по } 10 \text { мл у пластиковому фрлаконі-крапельниці; } \\
\text { по } 1 \text { фрлакону-крапельниці у картонній коробці }\end{array}$ \\
\hline & $\begin{array}{l}\text { ВЕТ-КОМОД краплі очні, } 20 \text { мг/мл по } 10 \text { мл у багатодозовому пластиковому } \\
\text { контейнері, оснащеному повітронепроникним насосом; по } 1 \text { контейнеру в } \\
\text { картонній коробці }\end{array}$ \\
\hline & СІКАПОС гель очний, 2 мг/г по 10 г у тубі, по 1 або 3 туби в коробці \\
\hline & $\begin{array}{l}\text { ХІЛО-КОМОД краплі очні } 1 \text { мг/мл, по } 10 \text { мл у багатодозовому контейнері, } \\
\text { оснащеному повітронепроникним насосом та закритому ковпачком, по } 1 \\
\text { контейнеру в картонній коробці }\end{array}$ \\
\hline & $\begin{array}{l}\text { ХІЛО-КОМОД ФОРТЕ краплі очні, } 2 \text { мг/мл, по } 10 \text { мл у багатодозовому контейнері, } \\
\text { оснащеному повітронепроникним насосом та закритому ковпачком, по } 1 \\
\text { контейнеру в картонній коробці }\end{array}$ \\
\hline & ХІЛО®-КЕА краплі очні контейнер багатодозовий 10 мл з насосом та ковпачком, № 1 \\
\hline \multicolumn{2}{|r|}{ Медичні вироби } \\
\hline \multicolumn{2}{|r|}{ 03. Офртальмологічні та оптичні вироби } \\
\hline Багатоцільові розчини & $\begin{array}{l}\text { АРТЕЛАК® СПЛЕСК РОЗЧИН ЗВОЛОЖУЮЧИЙ ДЛЯ ОЧЕЙ І КОНТАКТНИХ ЛІНЗ } \\
\text { розЧИН 0,24 \% фрлаКОН } 10 \text { мЛ, № } 1\end{array}$ \\
\hline \multirow{15}{*}{$\begin{array}{l}\text { Засоби для } \\
\text { остальмологічного } \\
\text { використання }\end{array}$} & ЛАКРІСЕК ОФТА ПЛЮС краплі очні фрлакон 8 мл, стерильний, № 1 \\
\hline & $\begin{array}{l}\text { АКВІЛА КРАПЛІ ОЧНІ краплі очні 0,18 \% контейнер полімерний 0,4 мл, } \\
\text { стерильний, № } 10\end{array}$ \\
\hline & КАТІОНОРМ КРАПЛІ ОЧНІ емульсія 10 мЛ, № 1 \\
\hline & ОКУТИАРЗ краплі очні фрлакон 10 мл, № 1 \\
\hline & ОПТИНОЛ® ІНТЕНСИВ краплі очні 10 мл № 1 \\
\hline & СИСТЕЙН АКВА ЗАСІБ ДЛЯ ЗВОЛОЖЕННЯ ОЧЕЙ 10 мЛ, № 1 \\
\hline & СИСТЕЙН БАЛАНС ЗАСІБ ДЛЯ ЗВОЛОЖЕННЯ ОЧЕЙ 10 МЛ, № 1 \\
\hline & СИСТЕЙН УЛЬТРА ЗАСІБ ДЛЯ ЗВОЛОЖЕННЯ ОЧЕЙ КОНТеЙНер 0,7 мЛ, № 30 \\
\hline & СИСТЕЙН УЛЬТРА ЗАСІБ ДЛЯ ЗВОЛОЖЕННЯ ОЧЕЙ фрЛаКОН 10 мЛ, № 1 \\
\hline & ЗАСІБ ДЛЯ ЗВОЛОЖЕННЯ ОЧЕЙ СИСТЕЙН фрЛакон 10 мЛ, № 1 \\
\hline & ЗАСІБ ДЛЯ ЗВОЛОЖЕННЯ ОЧЕЙ СИСТЕЙН® ГеЛЕВИЙ роЗЧИН 10 мЛ № 1 \\
\hline & СУПЕРОПТІКТм КОМПЛІТ краплі очні фрлакон 10 мл № 1 \\
\hline & УНІTІРС краплі очні фрлакон 10 мл, № 1 \\
\hline & КРАПЛІ ОЧНІ АЙ-ТІ ЕКТОІН ампула 0,5 мл, № 10 \\
\hline & КРАПЛІ ОЧНІ АЙ-ТІ ЕКТОІН ПРО ампула 0,5 мл, № 10 \\
\hline
\end{tabular}

ISSN 2312-0967. Pharmaceutical review. 2019. № 4 
Фармацевтичний менеджмент, маркетинг та логістика

Pharmaceutical management, marketing and logistics

Продовження табл. 1

\begin{tabular}{|c|c|}
\hline 1 & 2 \\
\hline \multicolumn{2}{|r|}{ 13. Інші вироби для лікування } \\
\hline \multirow{7}{*}{$\begin{array}{l}\text { Розчини для промивання, } \\
\text { зрошення, лікування }\end{array}$} & ВІАЛЬ® СЛЬОЗА краплі фрлакон поліетиленовий 10 мл, № 1 \\
\hline & ВІЗІЛОТОН ЗАСІБ ОФТАЛЬМОЛОГІЧНИЙ 10 мЛ, № 1 \\
\hline & ОПТІнОЛ 0,21 \% краплі очні 10 мл \\
\hline & ОПтІнОЛ 0,4 \% краплі очні 10 мл \\
\hline & ТЕАЛОЗ® ДУО РОЗЧИН ОФТАЛЬМОЛОГІЧНИЙ фрлакон 10 мЛ стериЛьний, № 1 \\
\hline & ГІПРОМЕЛОЗА-П, краплі очні 0,5 \% контейнер-крапельниця 10 мл, № 1 \\
\hline & СУПЕРОПТІК АКВА краплі очні фрлакон 5 мл, № 1, 2 \\
\hline
\end{tabular}

ких фрормах - розчин, очні краплі, емульсія. Отже, засоби для замісної терапії ССО, що фрізично доступні для пацієнтів в Україні, представлено у чотирьох форомах (рис. 1).

Зважаючи на це, доцільним вважали також проаналізувати вид первинної упаковки засобів, що використовуються для зволоження ока. В результаті дослідження встановили, що всі лікарські засоби фрармацевтична промисловість випускає у фрлаконах по 3, 5, 10 чи 15 мл. У фрлакони об'ємом 5 або 10 мл фасують також багатоцільовий розчин та розчини для промивання, зрошення, лікування. Проте варто зазначити, що серед засобів для офртальмологічного використання 4 найменування, що становить $25 \%$ від асортименту зазначеної групи та 11,8 \% в загальній номенклатурі, випускається у однодозових контейнерах.

Асортиментний аналіз за країною-виробником показав широку географрію розташування потужностей виробництва засобів для замісної терапії ССО. Так, лікарські засоби, що показані при ССО, виробляють у 4 країнах: Німеччині (72,7 \%), Бельгії, США та Індії по 9,1 \%. Багатоцільовий розчин імпортується $3 \mathrm{Hi-}$ меччини. Розчини для промивання, зрошення, лікування виробляють як в Україні (28,5 \%), так і за кордоном - у Хорватії (28,5 \%), Франції, Словаччині та Польщі (по 14,3 \%). Засоби для офртальмологічного використання здебільшого (93,75 \%) імпортують. Лідером 3 виробництва $€$ Іспанія (6 найменувань 37,5 \%). Також фрірми-виробники розташовано у Японії, Словаччині, Німеччині (по 2 найменування - по 12,5 \%), Хорватії та Польщі (по 1 найменуванню). Таким чином, вітчизняна промисловість забезпечує лише 8 \% асортиментного ряду засобів для замісної терапії ССО (рис. 2).

Механізм дії лікарських засобів - штучних замінників слізної рідини - забезпечують 7 активних фрармацевтичних інгредієнтів: натрію гіалуронат, карбомер, гіпромелоза, кармелоза, поліквад, повідон, полівініловий спирт (рис. 3).

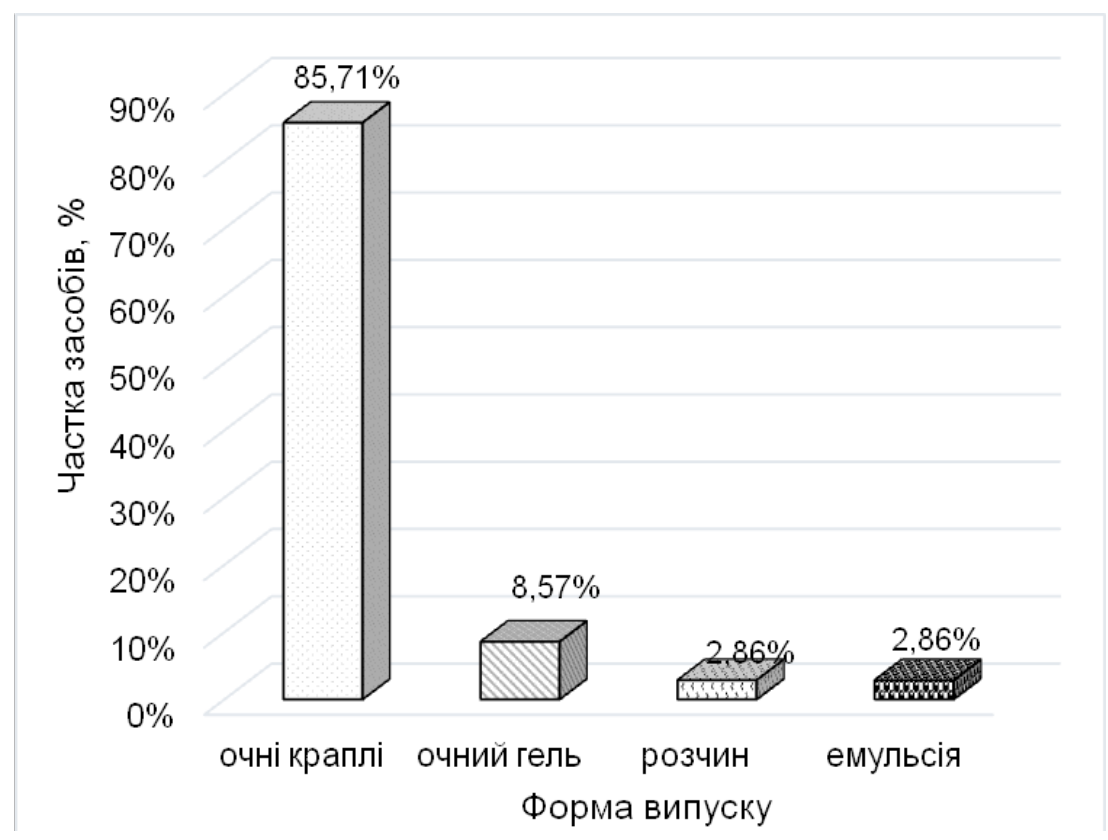

Рис. 1. Форми випуску засобів для замісної терапії синдрому сухого ока, зареєстрованих в Україні.

ISSN 2312-0967. Фармацевтичний часопис. 2019. № 4 
Фармацевтичний менеджмент, маркетинг та логістика Pharmaceutical management, marketing and logistics

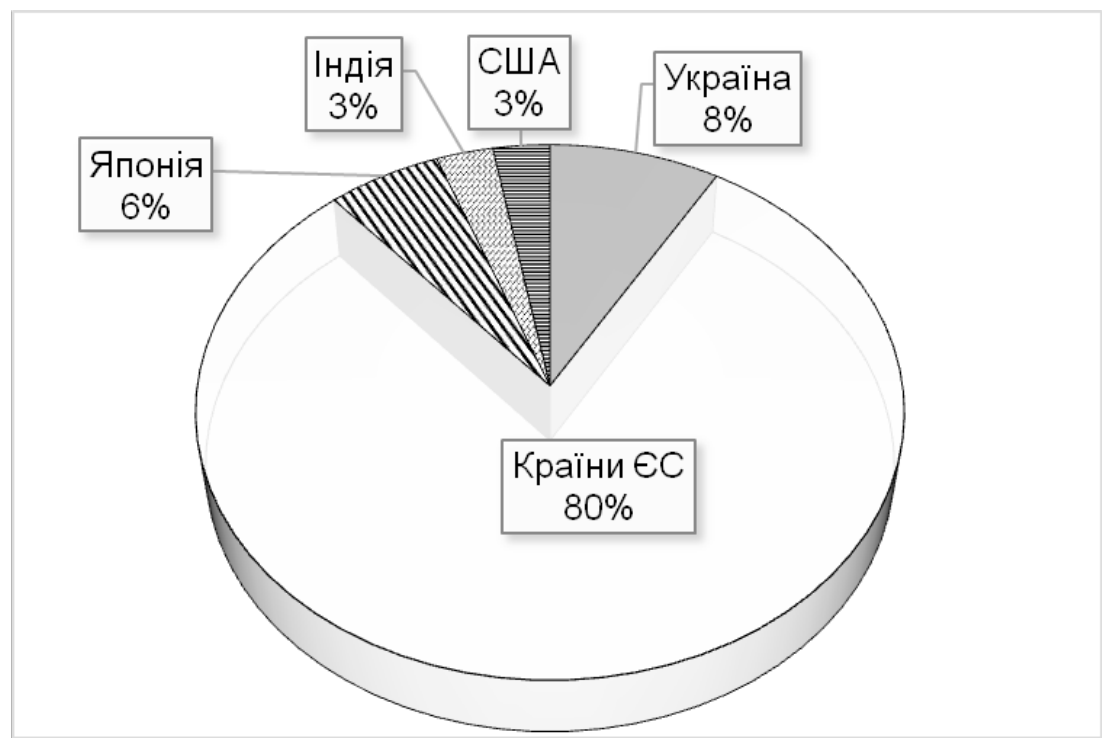

Рис. 2. Аналіз засобів для замісної терапії синдрому сухого ока за країною-виробником.

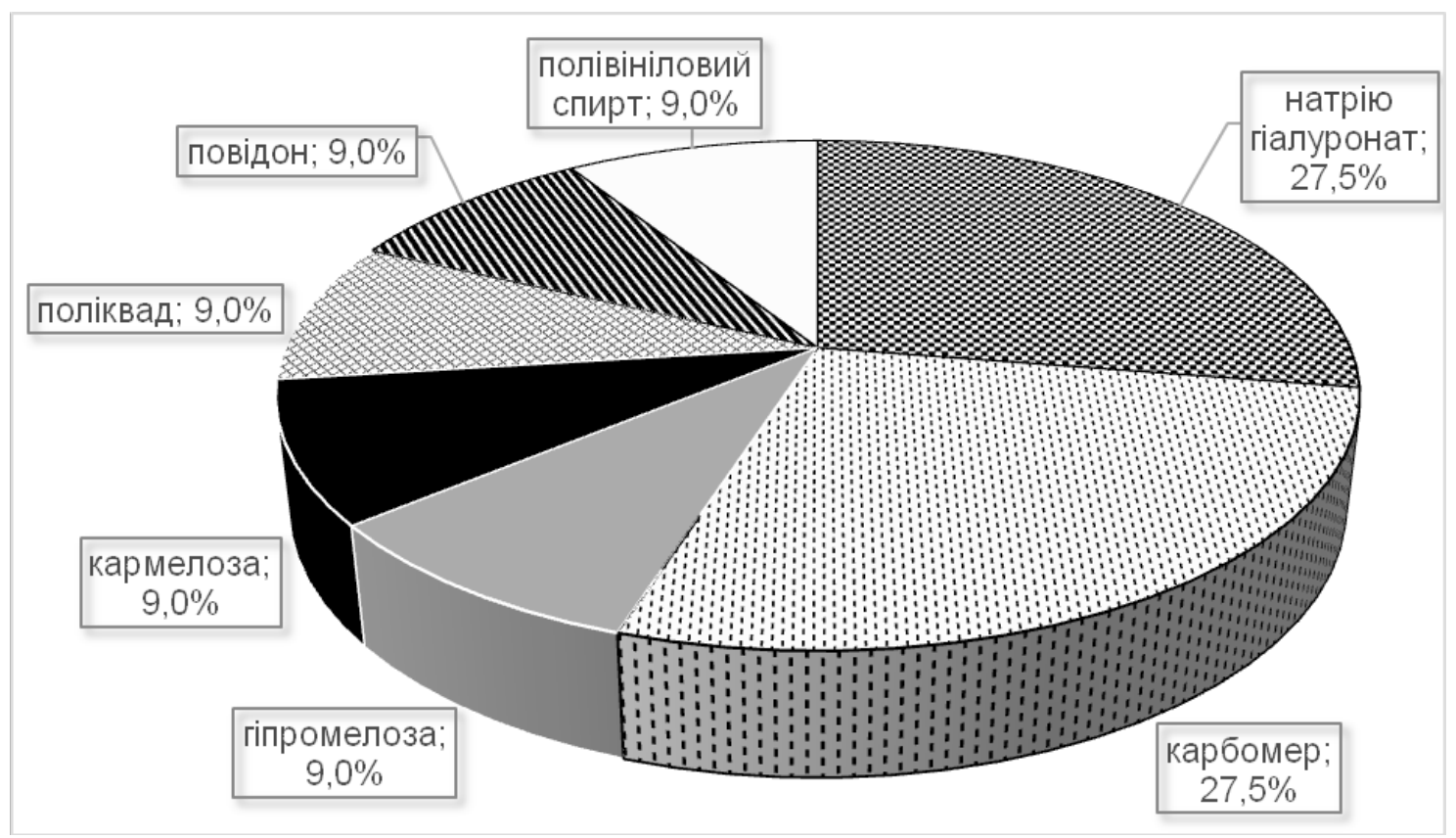

Рис. 3. Номенклатура активних фрармацевтичних інгредієнтів, що входять до складу лікарських засобів групи S01X A20 - «Штучні замінники слізної рідини та інші нейтральні препарати».

У складі медичних виробів для замісної місцевої терапії ССО, крім вищезазначених АФІ, які входять до ЛЗ, наявні декспантенол із таурином, трегалоза, комплекс вітамінів з амінокислотами, ектоїн, омега-3, поєднання натрію гіалуронату з пропіленгліколем та гуаром (рис. 4).

Отже, основним компонентом засобів замісної терапії CCO, представленим на фрармацевтичному ринку України, є натрію гіалуронат у чистому вигляді чи в поєднанні з пропіленгліколем та гуа- ром, що відповідає другій лінії терапії за Європейськими рекомендаціями ведення пацієнтів із ССО [4].

Висновки. Станом на 1 жовтня 2019 року для замісної терапії ССО в Україні використовують 35 найменувань засобів у фрормі очних крапель, очного гелю, розчинів та емульсії. Майже 90 \% 3 них випускають у фрлаконах по 3, 5, 10 чи 15 мл.

Більшість - 80 \% - засобів для замісної терапії ССО імпортують в Україну з країн Європи. До складу 
Фармацевтичний менеджмент, маркетинг та логістика

Pharmaceutical management, marketing and logistics

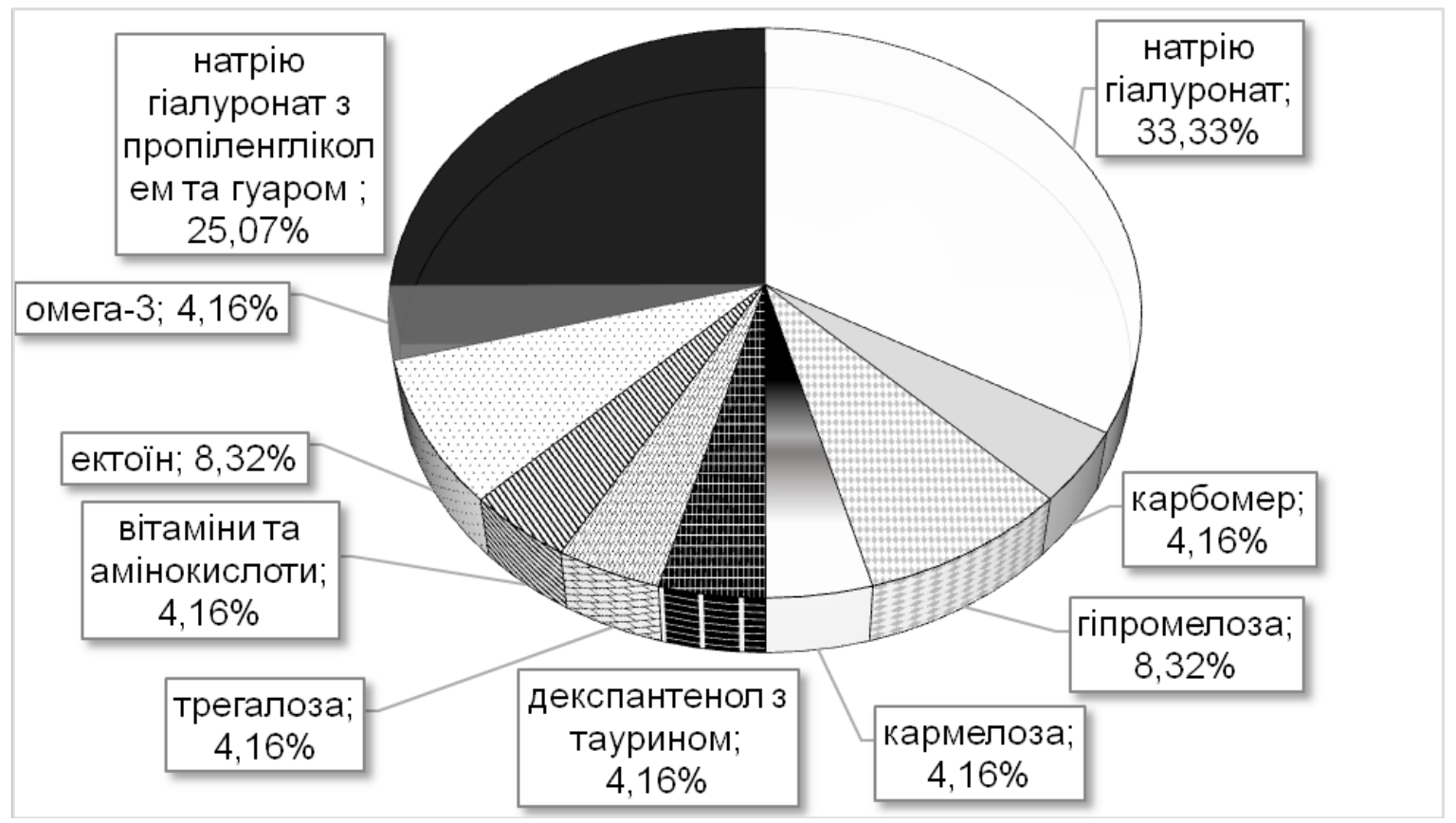

Рис. 4. Діючі речовини в складі медичних виробів, що застосовуються для замісної місцевої терапії синдрому сухого ока.

17 найменувань входить натрію гіалуронат в якості діючої субстанції.

Таким чином, у результаті проведених досліджень варто вказати на відсутність засобів для замісної терапії ССО у фрормі мазей. Крім того, слід звернути увагу як на недостатню кількість засобів зазначеної групи вітчизняного виробництва зага- лом, так і обмежений асортимент активних інгредієнтів, представлений лише натрію кармелозою, таурином із декспантенолом, а також натрію гіалуронатом.

Конфрлікт інтересів: відсутній.

Conflicts of interest: authors have no conflict of interest to declare.

\title{
REMEDIES FOR SUBSTITUTION THERAPY OF THE DRY EYE SYNDROME: ANALYSIS OF THE PHARMACEUTICAL MARKET OF UKRAINE
}

\section{O. V. Kryvoviaz, Yu. O. Tomashevska}

\author{
National Pirogov Memorial Medical University, Vinnytsya \\ 16124sk@gmail.com
}

The aim of the work. Analysis of remedies assortment for substitution therapy of dry eye syndrome that are available on the pharmaceutical market of Ukraine.

Materials and Methods. Marketing, statistical, structural, graphic.

Results and Discussion. There are 11 drugs of the S01X A20 group - "Artificial tear fluid substitutes and other neutral drugs" and 24 registered as medical devices, including 1 multi-purpose solution (group 03. Ophthalmic and optical products), 16 ophthalmic products (group 03. Ophthalmic and optical products) and 7 solutions for washing, irrigation, treatment (group 13. Other products for treatment) among the remedies for local substitutive therapy for dry eye syndrome. An analysis of the remedies forms for substitution therapy showed that in Ukraine they are presented in four forms: eye drops, eye gel, solutions, emulsions. Assortment analysis by producing countries indicated a wide location of production capacities. The mechanism of action of these remedies is provided by the presence of active ingredients such as sodium hyaluronate, carbomer, hypromellose, carmellose, polyquad, povidone, polyvinyl alcohol, dexpanthenol with taurine, trehalose, a complex of vitamins with aminoacids, ectoin, omega-3, a combination of sodium hyaluronate with propyleneglycol and guar.

Conclusions. 35 names of remedies are used in the form of eye drops, eye gel, solutions and emulsions for substitution therapy of dry eye syndrome in Ukraine. Almost $90 \%$ of them are produced in 3, 5, 10 or 15 ml vials. The vast majority -

ISSN 2312-0967. Фармацевтичний часопис. 2019. № 4 
$80 \%$ - of remedies for substitution therapy of dry eye syndrome are imported to Ukraine from European countries. The composition of 17 items includes sodium hyaluronate as an active substance.

Thus, it is worth to note the lack of remedies for the substitution therapy of dry eye syndrome in the form of ointments as a result of the conducted studies. In addition, attention should be paid both to the lack of remedies of this group of domestic production in general, and the limited range of active ingredients, represented only by carmellose sodium, taurine with dexpanthenol, and sodium hyaluronate.

Key words: dry eye syndrome, substitution therapy; tear fluid substitutes; marketing analysis.

\title{
СРЕДСТВА ДЛЯ ЗАМЕСТИТЕЛЬНОЙ ТЕРАПИИ СИНДРОМА СУХОГО ГЛАЗА: АНАЛИЗ ФАРМАЦЕВТИЧЕСКОГО РЫНКА УКРАИНЫ
}

\author{
Е. В. Кривовяз, Ю. А. Томашевская \\ Винницкий национальный медицинский университет имени Н. И. Пирогова \\ 16124sk@gmail.com
}

Цель работы. Анализ ассортимента средств для заместительной терапии синдрома сухого глаза (ССг), имеющихся на фрармацевтическом рынке Украины.

Материалы и методы. Маркетинговый, статистический, структурный, графический.

Результаты и обсуждение. Среди средств для местной заместительной терапии ССг насчитывается 11 лекарственных средств группы S01X A20 - «Искусственные заменители слезной жидкости и другие нейтральные препараты» и 24 зарегистрированных как медицинские изделия, в том числе 1 многоцелевой раствор (группа 03. Офртальмологические и оптические изделия), 16 средств для офтальмологического применения (группа 03. Оортальмологические и оптические изделия) и 7 растворов для промывания, орошения, лечения (группа 13. Другие изделия для лечения). Анализ форм выпуска средств для заместительной терапии показал, что в Украине они представлены в четырех фрормах: глазных капель, глазного геля, растворов, эмульсии. Ассортиментный анализ по странам-производителям показал широкую географию расположения мощностей производства. Механизм действия данных средств обеспечивается наличием таких активных ингредиентов, как натрия гиалуронат, карбомер, гипромеллоза, кармеллоза, поликвад, повидон, поливиниловый спирт, декспантенол с таурином, трегалоза, комплекс витаминов с аминокислотами, эктоин, омега-3, сочетание натрия гиалуроната с пропиленгликолем и гуаром.

Выводы. Для заместительной терапии Ссг в Украине используется 35 наименований средств в фрорме глазных капель, глазного геля, растворов и эмульсии. Почти 90 \% из них выпускается во фрлаконах по 3, 5, 10 или 15 мл. Подавляющее большинство - 80 \% - средств для заместительной терапии ССГ импортируется в Украину из стран Европы. В состав 17 наименований входит натрия гиалуронат в качестве действующей субстанции.

Таким образом, в результате проведенных исследований следует отметить отсутствие средств для заместительной терапии ССГ в форме мазей. Кроме того, необходимо обратить внимание как на недостаточное количество средств указанной группы отечественного производства в целом, так и ограниченный ассортимент активных ингредиентов, представленный только натрия кармеллозой, таурином с декспантенолом, а также натрия гиалуронатом.

Ключевые слова: синдром сухого глаза; заместительная терапия; заменители слезной жидкости; маркетинговый анализ.

\section{Список літератури}

1. Фармацевтична енциклопедія [Електронний ресурс]. - URL. : https://www.pharmencyclopedia.com.ua.

2. Craig JP, et al., TFOS DEWS II Report Executive Summary, The Ocular Surface (2017). - URL.: http://dx.doi. org/10.1016/j.jtos.2017.08.003.

3. Синдром сухого ока. Клінічна настанова, заснована на доказах, 2019 [Електронний ресурc]. - URL : http:// mtd.dec.gov.ua/index.php/uk/haluzevi-standarty-taklinichni-nastanovy/item/421-syndrom-sukhoho-oka.

4. Aneurin Bevan University Health Board. Dry Eye Management Guidelines (2016). - URL.: http://www.wales. nhs.uk/sites3/page. .fm?orgid=814\&pid=48819.
5. Державний реєстр лікарських засобів України (2019) [Електронний ресурc]. - URL. : http://www.drlz.com. ua/ibp/ddsite.nsf/all/shlist?opendocument.

6. Державний реєстр медичної техніки та виробів медичного призначення (2019) [Електронний ресурс]. - URL. : http://dls.gov.ua/wp-content/uploads/2018/07/ \%D0\%A0\%D0\%B5\%D0\%B5\%D0\%B5\%D1\%81\%D1\% 82\%D1\%80.pdf.

7. Довідник лікарських засобів Компендіум (2019) [Електронний ресурc]. - URL. : https://compendium.com.ua/uk.

8. Довідник еквівалентності лікарських засобів Rx index (2019) [Електронний ресурс]. - URL. : https://rx.ua.

ISSN 2312-0967. Pharmaceutical review. 2019. № 4 


\section{References}

1. Pharmaceutical encyclopedia. - Available from: https:// www.pharmencyclopedia.com.ua. Ukrainian.

2. Craig JP, et al., TFOS DEWS II Report Executive Summary, The Ocular Surface; 2017. Available from: http://dx.doi.org/10.1016/j.jtos.2017.08.003.

3. Dry eye syndrome. Evidence-based clinical guidance, 2019. Available from: http://mtd.dec.gov.ua/index.php/ uk/haluzevi-standarty-ta-klinichni-nastanovy/item/421syndrom-sukhoho-oka. Ukrainian.

4. Aneurin Bevan University Health Board. Dry Eye Management Guidelines (2016). Available from: http://www. wales.nhs.uk/sites3/page. $\mathrm{cfm}$ ?orgid=814\&pid=48819.

5. State Register of Medicines of Ukraine (2019). Available from: http://www.drlz.com.ua/ibp/ddsite.nsf/ all/shlist?opendocument. Ukrainian.

6. State Register of Medical Equipment and Medical Devices; 2019. Available from: http://dls.gov.ua/wpcontent/uploads/2018/07/\%D0\%A0\%D0\%B5\%D0\%B 5\%D0\%B5\%D1\%81\%D1\%82\%D1\%80.pdf. Ukrainian.

7. Medicines Reference Compendium; 2019. Available from: https://compendium.com.ua/uk. Ukrainian.

8. Medicines Equivalence Reference Rx index; 2019 Available from: https://rx.ua. Ukrainian.

\section{Відомості про авторів:}

Кривов'яз О. В. - д. фрармац. н., доцент, завідувач кафедри фрармації, Вінницький національний медичний університет імені М. І. Пирогова, Вінниця, Україна. E-mail: 16124sk@gmail.com, ORCID 0000-0001-5441-1903.

Томашевська Ю. О. - канд. фрармац. н., доцент кафедри фрармації, Вінницький національний медичний університет імені М. І. Пирогова, Вінниця, Україна. E-mail: tomasevskau@gmail.com, ORCID 0000-0001-9708-1887.

\section{Information about the authors:}

Kryvoviaz O. V. - DS (Pharmacy), Associate Professor, the head of the Pharmacy Department, National Pirogov Memorial Medical University, Vinnytsya, Ukraine. E-mail: 16124sk@gmail.com, ORCID 0000-0001-5441-1903.

Tomashevska Yu. O. - PhD (Pharmacy), Associate Professor of the Pharmacy Department, National Pirogov Memorial Medical University, Vinnytsya, Ukraine. E-mail: tomasevskau@gmail.com, ORCID 0000-0001-9708-1887. 